Research Paper

\title{
Electrooxidation of nickel-ammonia complexes and simultaneous electrodeposition recovery of nickel from practical nickel-electroplating rinse wastewater
}

\author{
Wei Guan ${ }^{\mathrm{a}, \mathrm{b}}$, Shichao Tian ${ }^{\mathrm{c}}$, Di Cao ${ }^{\mathrm{a}}$, Yutong Chen ${ }^{\mathrm{a}}$, Xu Zhao ${ }^{\mathrm{a}, \mathrm{d}, *}$ \\ a Key Laboratory of Drinking Water Science and Technology, Research Center for Eco-Environmental Sciences, Chinese Academy of Sciences, Beijing 100085, PR \\ China \\ ${ }^{\mathrm{b}}$ Chongqing Key Laboratory of Environmental Materials \& Remediation Technologies, Chongqing University of Arts and Sciences, Chongqing 402160, PR China \\ ${ }^{\mathrm{c}}$ Environmental Science and Technology Laboratory, Tsinghua-Berkeley Shenzhen Institute, Shenzhen 518055, PR China \\ d University of Chinese Academy of Sciences, No. 19(A) Yuquan Road, Shijingshan District, Beijing 100049, PR China
}

A R T I C L E I N F O

Article history:

Received 7 May 2017

Received in revised form 14 June 2017

Accepted 21 June 2017

Available online 23 June 2017

\section{Keywords:}

Electrodeposition

Electrooxidation

Nickel-ammonia complexes

Nickel recovery

Ammonia removal

\section{A B S T R A C T}

In this experiment, a combined electrooxidation-electrodeposition (EO-ED) system using $\mathrm{RuO}_{2} / \mathrm{Ti}_{\text {anode }}$ and stainless steel cathode was employed to treat nickel-ammonia complexes wastewater, which simultaneously achieved the decomplexation of nickel-ammonia complexes and recovery of nickel metal. Effects of current density, $\mathrm{pH}$ value and reaction temperature on electrochemical performance were analyzed. When the current density was $32 \mathrm{~mA} / \mathrm{cm}^{2}, \mathrm{pH}$ was 9.0 and the temperature was $60{ }^{\circ} \mathrm{C}$, the nickel recovery percentage was $99 \%$ and the ammonia removal efficiency was $70 \%$. Combined with the SEM-EDX, XRD and XPS analysis for the cathode surface, it was confirmed that the generation of deposition on the cathode surface was zero-valent nickel. Firstly, Nickel-ammonia complexes were destroyed by electrooxidation process, generating $\mathrm{Ni}^{2+}$ ions and free $\mathrm{NH}_{3}$. Then, $\mathrm{Ni}^{2+}$ ions were reduced onto the cathode and free $\mathrm{NH}_{3}$ were further oxidized. Stability of the system for nickel-ammonia complexes treatment was examined by repeated experiments for fifteen successive cycles. The electrochemical system exhibited a satisfactory stability for nickel recovery and ammonia removal, achieving nickel recovery percentage of 85-95\% and ammonia removal efficiency of 65-70\%, respectively. (C) 2017 Published by Elsevier Ltd.

\section{Introduction}

The nickel-ammonia complexes in wastewater has attracted the attention due to its large discharge and high toxicity to the ecosystem, which mainly comes from industrial process such as electroplating industry, hard alloy, high efficiency catalysts, coated materials and multilayer ceramic capacitors $[1,2]$. Ammonia and nickel ions $\left(\mathrm{Ni}^{2+}\right)$ can form metal complexes, which is difficult to be removed by traditional chemical precipitation [3,4]. Advanced oxidation processes have been largely investigated for treating refractory organics and organic complexes. Applications of photocatalysis [5], sonochemical process [6] and $\mathrm{H}_{2} \mathrm{O}_{2}$ /ultraviolet (UV) process [7] in treatment of metal-binding complexes have been

\footnotetext{
* Corresponding author at: P.O. Box 2871, 18 Shuangqing Road, Haidian District, Beijing, 10085, PR China.

E-mail address: zhaoxu@rcees.ac.cn (X. Zhao).
}

studied. Therefore, a reliable and cost-effective method for treating nickel-ammoarnia complexes is desired.

Previous studies on the removal or recovery of nickel ions included adsorption [8], ion-exchange [9], electrodialysis [10] and electrodeposition [11]. These methods have high removal efficiencies for nickel ions in wastewater. However, these methods are limited for ammonia removal. Biotreatment, electrooxidation and UV/chlorine methods have been used for ammonia removal, but the recovery efficiency of nickel ions is limited using these methods [12-14]. Some electrochemical techniques such as electrocoagulation, electrodeionization and electrodeposition [15-17] are usually used for the recovery of dissolved metal ions from industrial effluent streams. However, these methods are limited for treating metal complexes [18,19].

Although some researches on nickel recovery and ammonia removal have been done, the treatment of nickel-ammonia complexes and simultaneous recovery of nickel from wastewater in pilot or full-scale studies is rarely reported [20-22]. The environmental, technological and economic methods need to be 
addressed with additional work, such as the optimum design of the electrochemical cells/reactors and the determination of optimal operating conditions $[23,24]$. Electrolysis has been considered as a promising technology for ammonia removal due to its high robustness, versatility and amenability to automation [25,26]. However, oxidation of nickel-ammonia complexes at the anode and the recovery of nickel ions at the cathode have not been achieved in practical nickel-electroplating rinse wastewater treatment.

Herein, decomplexation of nickel-ammonia complexes and simultaneous recovery of nickel could be achieved by the combination of electro-oxidation and electro-deposition. In this experiment, effects of current density, $\mathrm{pH}$ value and reaction temperature were analyzed. The cathode surface was analyzed by SEM-EDX, XRD and XPS techniques. The mechanism of reaction for treating nickel-ammonia complexes was explored.

\section{Experimental}

\subsection{Materials}

Sodium perchlorate, sodium hydroxide, nitric acid and sulfuric acid (98\% w/w) were purchased from Sinophorm Chemical Regent Co., Ltd. Deionized water was used for preparation and dilution of all solutions. $\mathrm{RuO}_{2} / \mathrm{Ti}$ anode and stainless steel cathode were purchased from Beijing Henglitai Corporation. The $\mathrm{RuO}_{2} / \mathrm{Ti}$ electrode used in this system was called dimensionally stable anodes (DSA), which had more advanced performance (catalytic activity, stability and low cost) than those of conventional electrodes (metal, carbon, etc) [27]. The target wastewater was the practical nickel-electroplating rinse wastewater. The initial concentration of nickel ions was $2156 \pm 50(\mathrm{mg} / \mathrm{L})$ and ammonia concentration was $9680 \pm 50(\mathrm{mg} / \mathrm{L})$. The initial $\mathrm{pH}$ of the solution was $8.8 \pm 0.2$.

\subsection{Experiment procedures}

The experiments were performed in a glass reactor with $250 \mathrm{~mL}$ and the sodium perchlorate acted as an electrolyte. The electrochemical system included a direct-current (DC) power supply, an electrolytic cell, a stainless steel cathode, a $\mathrm{RuO}_{2} / \mathrm{Ti}$ mesh anode and a magnetic stirring apparatus. The electrochemical experiments were carried out at a constant current density, which was controlled by a DC power supply (DH1718E-6, Dahua Electronic, Co., Ltd., Beijing, China). The $\mathrm{RuO}_{2} / \mathrm{Ti}$ electrode $(70 \mathrm{~mm}$ $\times 40 \mathrm{~mm} \times 0.5 \mathrm{~mm}$ ) was directly connected to the positive electrode of the DC power supply and the stainless steel electrode with the same area was directly connected to the negative electrode of the DC power supply. The reaction solution was stirred magnetically at a speed of $450 \mathrm{rpm}$ and heated by magnetic stirring apparatus. The power of the magnetic stirring apparatus was $15 \mathrm{~W}$ (OS20-Pro, Dragon Laboratory Instruments Limited, Beijing, China). Effects of current density $\left(8,16,24,32\right.$ and $\left.40 \mathrm{~mA} / \mathrm{cm}^{2}\right)$, $\mathrm{pH}$ values (3.0, 5.0, 7.0, 9.0 and 11.0) and reaction temperature (20, 40,60 and $80^{\circ} \mathrm{C}$ ) on the treatment of nickel-ammonia complexes were investigated. The $\mathrm{pH}$ was adjusted by $\mathrm{H}_{2} \mathrm{SO}_{4}(0.2 \mathrm{M})$ or $\mathrm{NaOH}$ solution $(0.2 \mathrm{M})$.

\subsection{Analysis}

Concentration of $\mathrm{Ni}^{2+}$ ions was measured using a 710 series inductively coupled plasma optical emission spectrometer (ICPOES, Agilent Technology, U.S.A.). Concentration of ammonia was detected according to the standard methods and $\mathrm{pH}$ value was measured with a pH meter [28]. The deposition on the cathode was analyzed by scanning electron microscope (SEM, model 6700F,
Tokyo, Japan) and energy dispersive X-ray analysis (EDX) (JEOL, Japan). X-ray powder diffraction (XRD) patterns were obtained with an X'Pert PRO Powder diffractometer machine (PANalytical Co.) by using $\mathrm{Ni}$-filtered $\mathrm{Cu} \mathrm{K}_{\alpha}$ radiation from $10^{\circ}$ to $90^{\circ}$ [29]. X-ray photoelectron spectra (XPS) was used to analyze the surface variation of the electrode using a PHI Quantera SXM (PHI-5300/ ESCA, ULVAC-PHI, INC) [30].

\section{Results and discussion}

\subsection{Effect of current density on electrochemical performance}

The performance of electrochemical system for Ni recovery and ammonia removal was investigated. The equations about recovery percentage of Ni ions (RP) and removal efficiency of ammonia (RE) were defined using the following Eqs. (1)-(2) [31] :

$\mathrm{RP}=\frac{\mathrm{C}_{0}-\mathrm{C}_{\mathrm{t}}}{\mathrm{C}_{0}} \times 100 \%$

Where $C_{0}$ is the concentration of nickel ions at the initial time, $\mathrm{mg} /$ $\mathrm{L} ; \mathrm{C}_{\mathrm{t}}$ is the concentration of nickel ions at a given time, $\mathrm{mg} / \mathrm{L}$.

$\mathrm{RE}=\frac{\mathrm{C}_{0}-\mathrm{C}_{\mathrm{t}}}{\mathrm{C}_{0}} \times 100 \%$

Where $\mathrm{C}_{0}$ is the concentration of ammonia at the initial time, $\mathrm{mg} / \mathrm{L}$; $\mathrm{C}_{\mathrm{t}}$ is the concentration of ammonia at a given time, $\mathrm{mg} / \mathrm{L}$.

The Effect of current density on nickel ions recovery and ammonia removal was investigated. As shown in Fig. 1(a), corresponding to the current density of $8 \mathrm{~mA} / \mathrm{cm}^{2}, 16 \mathrm{~mA} / \mathrm{cm}^{2}$, $24 \mathrm{~mA} / \mathrm{cm}^{2}, 32 \mathrm{~mA} / \mathrm{cm}^{2}$ and $40 \mathrm{~mA} / \mathrm{cm}^{2}$, the recovery percentage of nickel ions are $29.14 \%, 77.83 \%, 90.12 \%, 98.26 \%$ and $99.03 \%$ after a $180 \mathrm{~min}$ reaction. The recovery percentage of nickel ions is increased with increasing current density. The recovery rate of nickel ions is fast and the kinetics process is current density control in the first $2 \mathrm{~h}$ (Figure SM-1). In addition, the increasing current density enhances the removal efficiency of ammonia (Fig. 1(b)).

The electrode potentials were measured as $1.0 \mathrm{~V}, 2.6 \mathrm{~V}, 3.8 \mathrm{~V}$, $4.2 \mathrm{~V}$ and $6.0 \mathrm{~V}$ for the applied current densities of $8 \mathrm{~mA} / \mathrm{cm}^{2}$, $16 \mathrm{~mA} / \mathrm{cm}^{2}, 24 \mathrm{~mA} / \mathrm{cm}^{2}, 32 \mathrm{~mA} / \mathrm{cm}^{2}$ and $40 \mathrm{~mA} / \mathrm{cm}^{2}$, respectively. The increased current density would improve electrode potential in the system, so the oxidation ability of the anode was enhanced. In addition, the nickel ions were reduced onto the cathode via Eq. (3).

$\mathrm{Ni}^{2+}(\mathrm{aq})+2 \mathrm{e}^{-} \rightarrow \mathrm{Ni}(\mathrm{s})$

But when the current density increased from 32 to $40 \mathrm{~mA} / \mathrm{cm}^{2}$, the recovery percentage of nickel ions remained nearly unchanged. The kinetics process was changed from current control to mass transport control. When the current density was $32 \mathrm{~mA} / \mathrm{cm}^{2}$, the recovery percentage of nickel ions was $98 \%$. In the actual wastewater treatment, both of the recovery efficiency of metals and low energy consumption were taken into account. Therefore, the optimal current density for this system was $32 \mathrm{~mA} / \mathrm{cm}^{2}$.

\subsection{Effect of $\mathrm{pH}$ value on the electrochemical performance}

Recovery efficiency of nickel ions and removal efficiency of ammonia at various $\mathrm{pH}$ values were analyzed. As shown in Fig. 2(a), the recovery efficiency of nickel ions is increased with increasing $\mathrm{pH}$ value. Comparing with recovery efficiency of nickel ions at different $\mathrm{pH}$ conditions, after a $180 \mathrm{~min}$ reaction, the recovery efficiency of nickel at $\mathrm{pH}=9.0$ and $\mathrm{pH}=11.0$ is the same. But insoluble hydroxides (such as $\mathrm{Ni}(\mathrm{OH})_{2}$ ) at the cathode surfaces are easily formed at high $\mathrm{pH}$ condition $(\mathrm{pH}>10.0)$, which influences the purity of nickel recovery. However, in the 

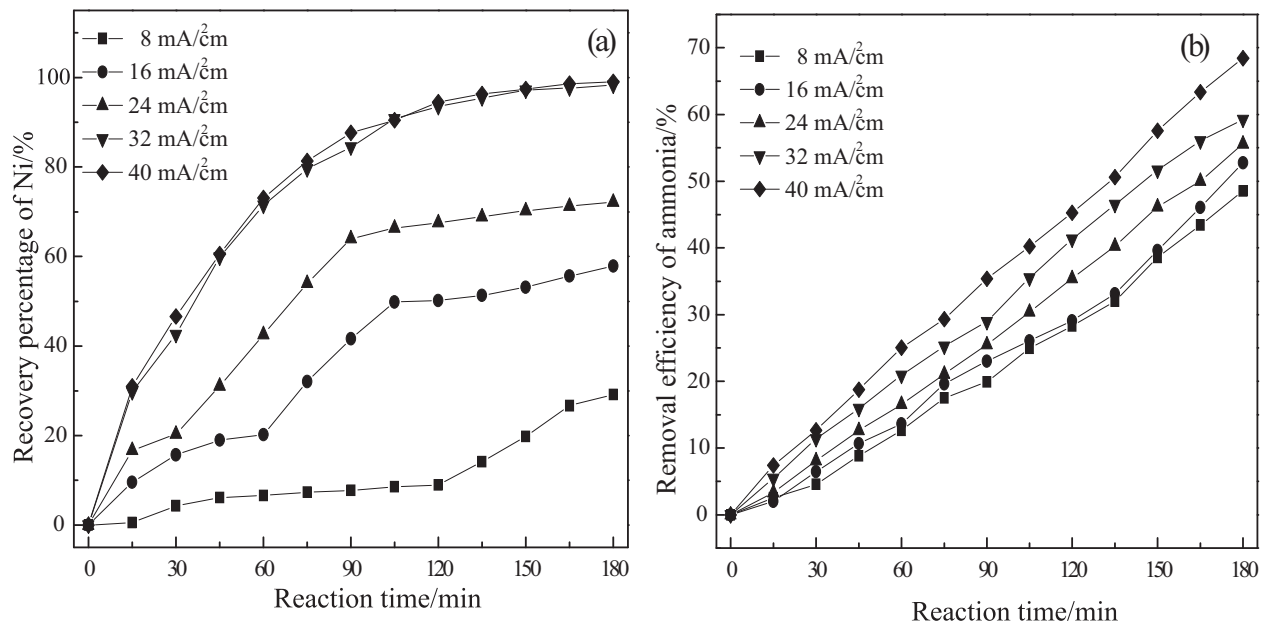

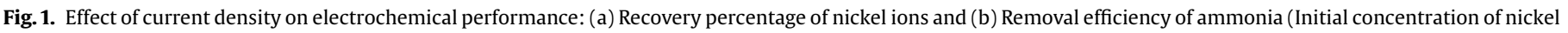
ions, $2156 \mathrm{mg} / \mathrm{L} ; \mathrm{pH}, 9.0$; reaction temperature, $40^{\circ} \mathrm{C}$ ).

electrochemical system, no isolation of the reactor was provided and nickel carbonate could be deposited on the electrode in alkaline media. The $\mathrm{pH}$ value played an important role on the morphology of the deposition. As shown in Fig. 2(b), the removal efficiency of ammonia is higher in alkaline condition. According to the report, the oxidation of ammonia required high $\mathrm{pH}$ values $(\mathrm{pH}=9.0)$ [32]. The ammonia in water exists in two forms: ammonium ions and free ammonia. The proportion of free ammonia is increased with increasing $\mathrm{pH}$ via the Eq. (4).

$\mathrm{NH}_{4}{ }^{+}+\mathrm{OH}^{-} \rightarrow \mathrm{NH}_{3}+\mathrm{H}_{2} \mathrm{O}$

The removal efficiency of ammonia rapidly increased from $\mathrm{pH}=9.0$ to $\mathrm{pH}=11.0$ (Figure $\mathrm{SM}-2$ ). At higher $\mathrm{pH}$ condition, ammonia was transformed to ammonia gas and vitalized to air, which required further treatment. In addition, the initial $\mathrm{pH}$ of the solution was $8.8 \pm 0.2$, without addition of $\mathrm{H}_{2} \mathrm{SO}_{4}$ or $\mathrm{NaOH}$ solution to adjust the $\mathrm{pH}$. Therefore, the optimal $\mathrm{pH}$ for this system was 9.0.

\subsection{Effect of reaction temperature on the electrochemical performance}

Recovery efficiency of nickel ions and removal efficiency of ammonia in various temperatures were analyzed. As shown in Fig. 3(a), the reaction temperature has an obvious effect on the recovery of nickel ions. When the temperature is higher than $60^{\circ} \mathrm{C}$, the recovery efficiency of nickel ions increases in the initial $90 \mathrm{~min}$, and remains unchanged with the extension of reaction time. When the temperature is lower than $40^{\circ} \mathrm{C}$, the recovery percentage of nickel ions is increased continuously with the extended reaction time. A different trend is observed in the EO process of ammonia (Fig. 3(b)). The removal efficiency of ammonia is obviously changed during the last $90 \mathrm{~min}$. These interesting results imply that nickelammonia complexes are destroyed by EO process in the initial $90 \mathrm{~min}$, and $\mathrm{Ni}^{2+}$ ions are reduced onto the cathode at the same time. Then, free $\mathrm{NH}_{3}$ generated from the destruction of nickelammonium complexes is further oxidized by the EO process. The removal efficiency of ammonia is increased quite quickly from
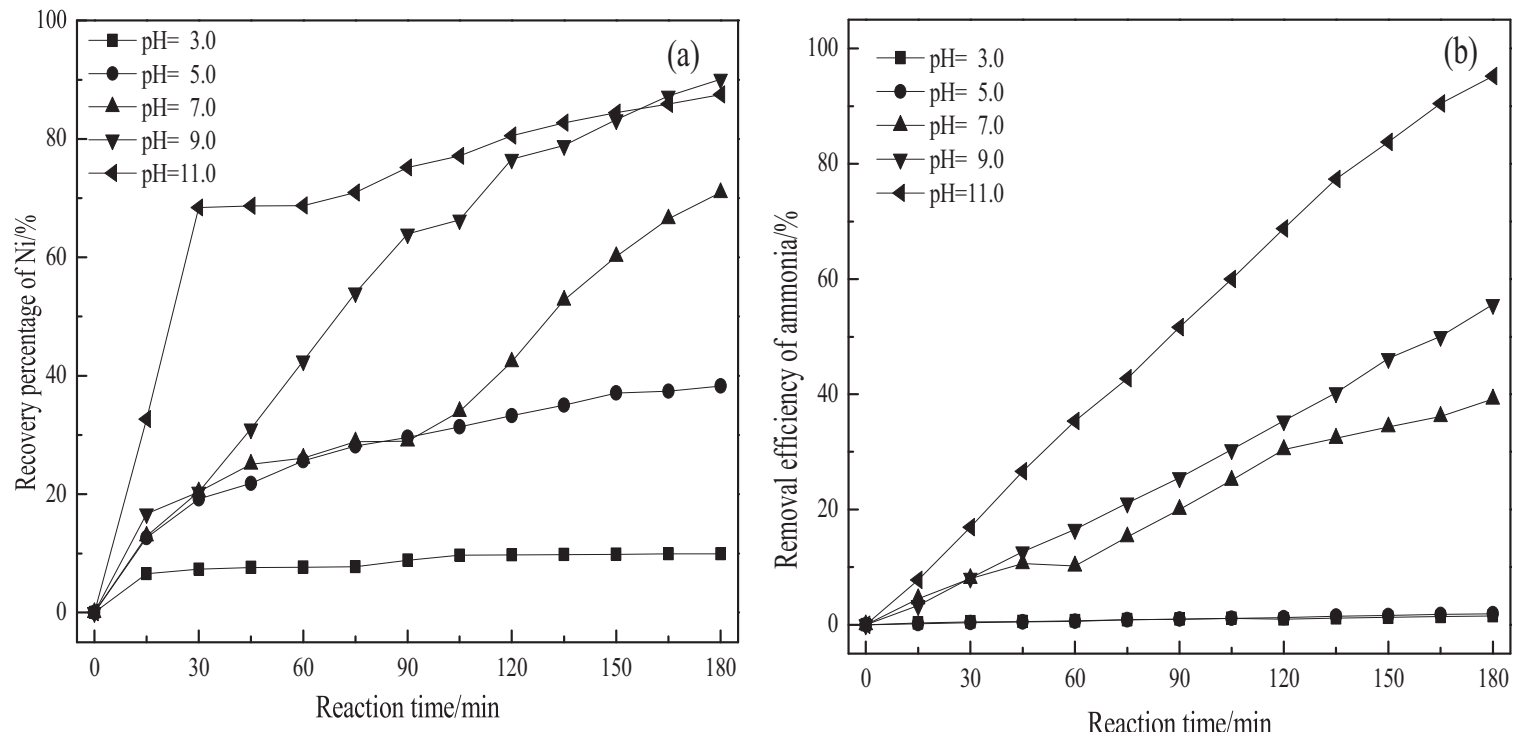

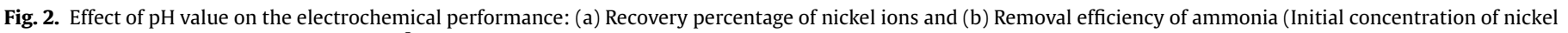
ions, $2156 \mathrm{mg} / \mathrm{L}$; current density, $32 \mathrm{~mA} / \mathrm{cm}^{2}$; reaction temperature, $40^{\circ} \mathrm{C}$ ). 

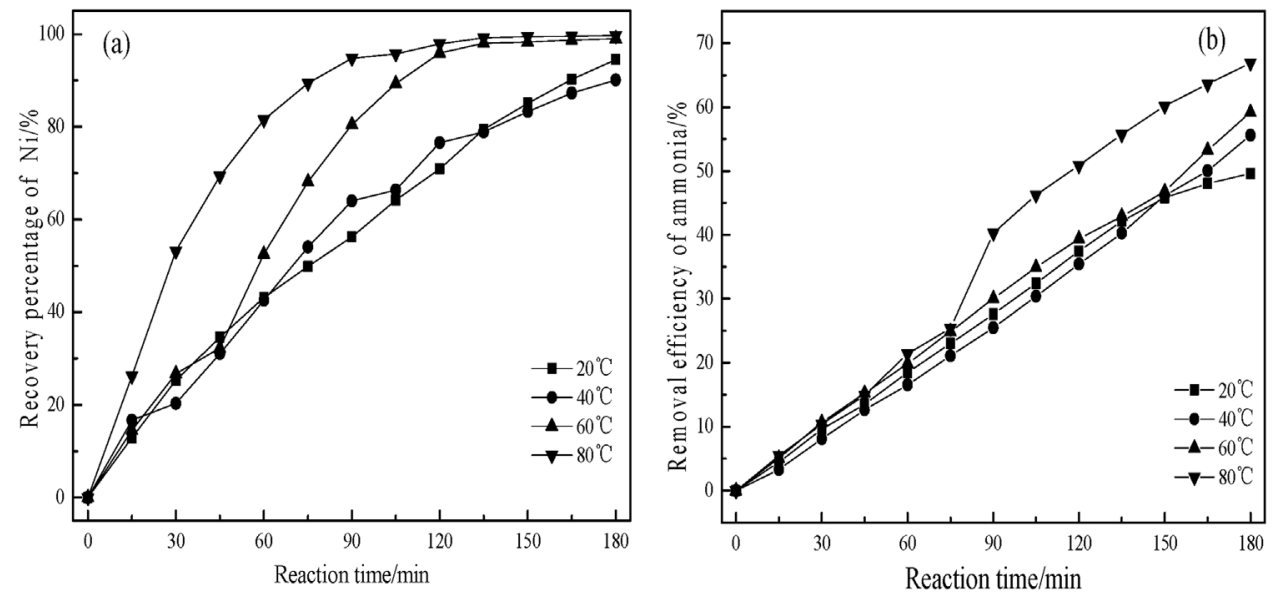

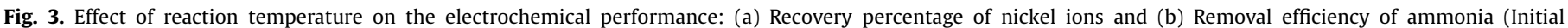
concentration of nickel ions, $2156 \mathrm{mg} / \mathrm{L}$; current density, $32 \mathrm{~mA} / \mathrm{cm}^{2} ; \mathrm{pH}, 9.0$ ).
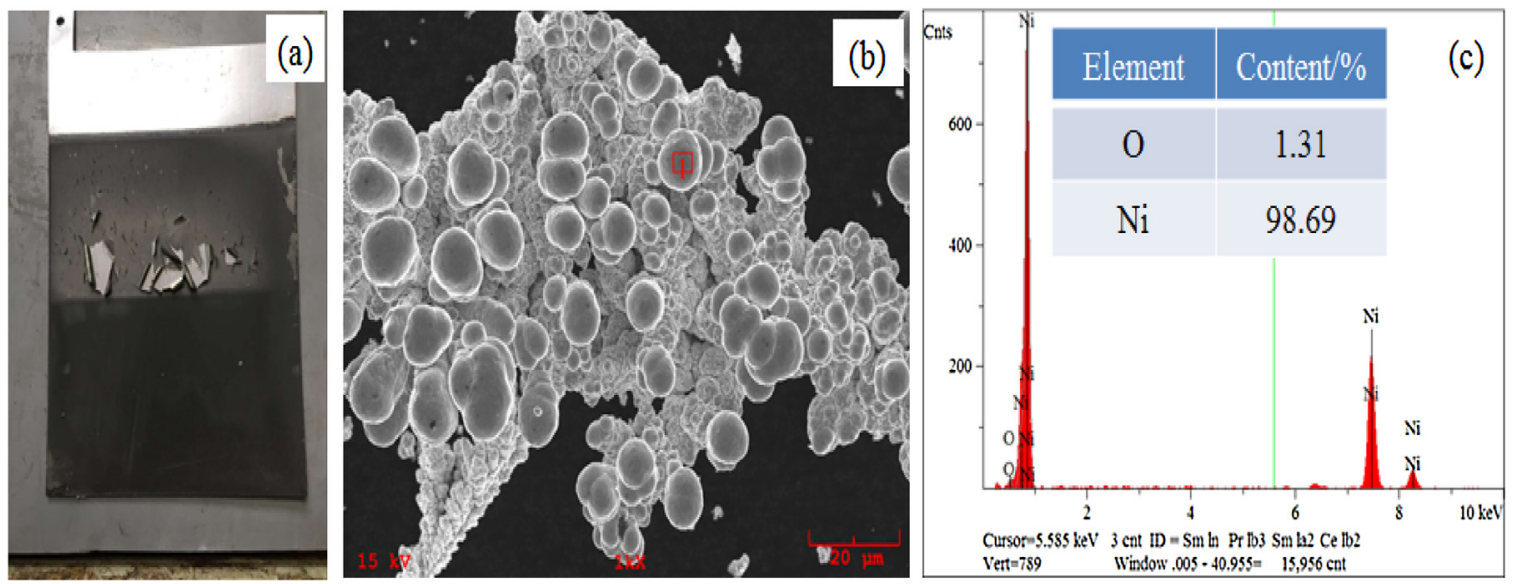

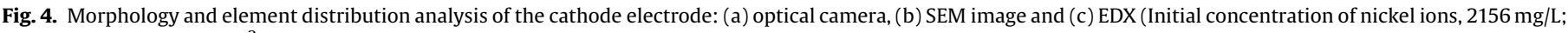
current density, $32 \mathrm{~mA} / \mathrm{cm}^{2}$; $\mathrm{pH}, 9.0$; reaction temperature, $60^{\circ} \mathrm{C}$ ).

$60^{\circ} \mathrm{C}$ to $80^{\circ} \mathrm{C}$ (Figure SM-3). In addition, considering the energy consumption, the optimum temperature for treating nickelammonia complexes was $60^{\circ} \mathrm{C}$.

\subsection{Surface variation of the cathode}

The deposition on the surface of stainless steel cathode was investigated by SEM-EDX, XRD and XPS. As shown in Fig. 4(a, b), there is some deposition on the cathode. In the process of nickelammonia complexes oxidation, nickel-ammonia is destroyed and nickel ions are reduced onto the cathode. Meantime, EDX spectra of the deposition on the cathode after a $180 \mathrm{~min}$ reaction are shown in Fig. 4(c). EDX spectra results declare that the major elements of the deposition are $\mathrm{Ni}$ and $\mathrm{O}$. Therefore, the results indicate the deposition on the cathode contains Ni element.

The structural properties of the deposition on the cathode were further investigated by XRD in the range of $10-90^{\circ}$. As shown in Fig. 5, the pronounced diffraction peaks in the XRD pattern at $2 \theta$ of $44.80^{\circ}, 52.75^{\circ}$ and $77.52^{\circ}$ are corresponded to (110), (200) and (220) Bragg's reflections of monoclinic Ni phase in accordance with the standard [33]. Furthermore, the intensity of the diffraction peaks is increased as the reaction is prolonged. The result indicates that the zero-valent nickel is gradually crystallized during the ED process. X-ray photoelectron spectroscopy (XPS) was used to analyze the chemical nature and oxidation state of the electrodeposited film on the cathode. As shown in Fig. 6, the XPS spectra of the Ni2p core level binding energy shows that the major $\mathrm{Ni}_{2} \mathrm{p}_{3 / 2}$ appears at $856.15 \mathrm{eV}$ and $861.50 \mathrm{eV}$. In addition, the major $\mathrm{Ni} 2 \mathrm{p}_{1 / 2}$ peaks centers at $874.26 \mathrm{eV}$. The results indicate the deposition on the cathode is assigned to zero-valent nickel. Thus, it

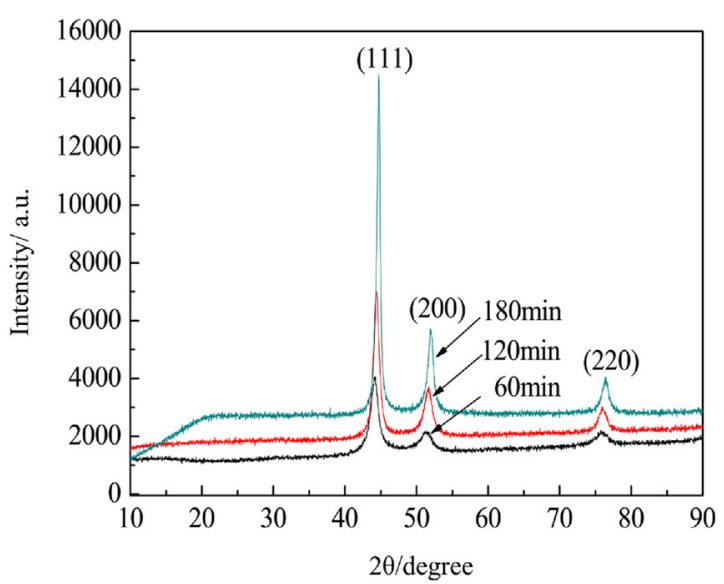

Fig. 5. XRD patterns of deposit on the cathode in the electrodeposition process (Initial concentration of nickel ions, $2156 \mathrm{mg} / \mathrm{L}$; current density, $32 \mathrm{~mA} / \mathrm{cm}^{2} ; \mathrm{pH}$, 9.0; reaction temperature, $60^{\circ} \mathrm{C}$ ). 


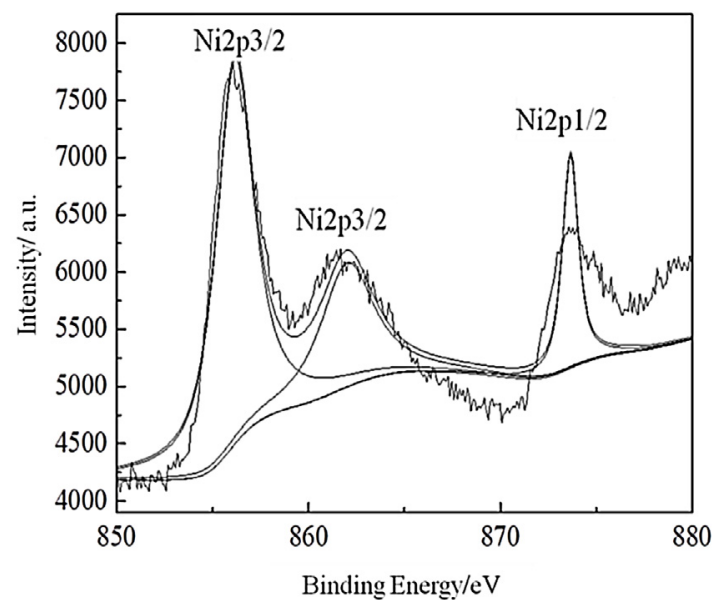

Fig. 6. X-ray photoelectron spectra (XPS) analysis of the deposit on the cathode in the electrodeposition process (Initial concentration of nickel ions, $2156 \mathrm{mg} / \mathrm{L}$; current density, $32 \mathrm{~mA} / \mathrm{cm}^{2}$; $\mathrm{pH}, 9.0$; reaction temperature, $60^{\circ} \mathrm{C}$ ).

is concluded that the nickel ions are reduced onto the cathode by the electrochemical process [34].

\subsection{A proposed electrooxidation pathway of nickel-ammonia complexes}

In the electrochemical system, the nickel-ammonia complexes were destroyed by anode oxidation in the initial $90 \mathrm{~min}$, generating $\mathrm{Ni}^{2+}$ ions and free $\mathrm{NH}_{3}$. Then $\mathrm{Ni}^{2+}$ ions were reduced on the cathode and the free $\mathrm{NH}_{3}$ were further oxidized by the generated $\mathrm{HOCl}$. The mechanism of ammonia oxidation had been widely studied $[35,36]$. The ammonia was decomposed via direct (non-mediated) electro-oxidation and indirect oxidation by active radicals such as hydroxyl radicals and hypochlorite ion [37]. In the electrochemical system, the $\mathrm{Cl}_{2}$ was generated in situ by $\mathrm{Cl}^{-}$ions losing two electrons on the anode and then converted to hypochlorous acid in alkaline condition. The ammonia could be completely oxidized by hypochlorous acid and most of the ammonia was converted into $\mathrm{N}_{2}$. The reactions result from the indirect oxidation by $\mathrm{HOCl}$ as shown in the following Eqs. (5)-(10).

At the anode: $2 \mathrm{Cl}^{-} \rightarrow \mathrm{Cl}_{2}+2 \mathrm{e}^{-}$

In solution: $\mathrm{Cl}_{2}+\mathrm{H}_{2} \mathrm{O} \rightarrow \mathrm{HOCl}+\mathrm{H}^{+}+\mathrm{Cl}^{-}$

$\mathrm{HOCl}+(2 / 3) \mathrm{NH}_{3} \rightarrow(1 / 3) \mathrm{N}_{2}+\mathrm{H}_{2} \mathrm{O}+\mathrm{H}^{+}+\mathrm{Cl}^{-}$

$\mathrm{HOCl}+(2 / 3) \mathrm{NH}_{4}^{+} \rightarrow(1 / 3) \mathrm{N}_{2}+\mathrm{H}_{2} \mathrm{O}+(5 / 3) \mathrm{H}^{+}+\mathrm{Cl}^{-}$

$\mathrm{HOCl}+(1 / 4) \mathrm{NH}_{4}{ }^{+} \rightarrow(1 / 4) \mathrm{NO}_{3}{ }^{-}+(1 / 4) \mathrm{H}_{2} \mathrm{O}+(3 / 2) \mathrm{H}^{+}+\mathrm{Cl}^{-}$

$\mathrm{HOCl}+(1 / 2) \mathrm{OCl}^{-} \rightarrow(1 / 2) \mathrm{ClO}_{3}{ }^{-}+\mathrm{H}^{+}+\mathrm{Cl}^{-}$

During the oxidation process of ammonia, the catalytic activity of the anode decreased due to the adsorbed $\mathrm{NH}_{\text {ads }}$ on the surface of the anode. The formation mechanism of $\mathrm{NH}_{\text {ads }}$ and $\mathrm{NH}_{2(\mathrm{ads})}$ could be described by the following Eqs. (11)-(14) [38].

$\mathrm{NH}_{3}(a q) \rightarrow \mathrm{NH}_{3(a d s)}$
$\mathrm{NH}_{3(\text { ads })} \rightarrow \mathrm{NH}_{2(a d s)}+\mathrm{H}^{+}+e^{-}$

$\mathrm{NH}_{2(a d s)} \rightarrow \mathrm{NH}_{\text {ads }}+\mathrm{H}^{+}+\mathrm{e}^{-}$

$\mathrm{NH}_{\text {ads }} \rightarrow \mathrm{N}_{\text {ads }}+\mathrm{H}^{+}+\mathrm{e}^{-}$

Therefore, the stability of this electrochemical system for destroying nickel-ammonia complexes should be analyzed.

\subsection{Stability of the electrochemical system and energy consumption}

Stability of the system for destroying nickel-ammonia complexes was studied by repeating the experiment for fifteen successive cycles. Before each cycle, the anode and cathode were washed with dilute nitric acid and then washed by deionized water. As shown in Fig. 7, the recovery percentage of $\mathrm{Ni}$ and removal efficiency of ammonia remains nearly constant for fifteen cycles. Nickel-ammonia complexes are oxidized by the anode and then nickel ions are reduced to zero-valent nickel. Thus, the system exhibits high stability for ammonia removal and nickel recovery.

Energy consumption is an estimate for the degradation of $1 \mathrm{~g}$ contaminant in an electrochemical system. During the oxidation process of nickel-ammonia complexes, the main energy consumption includes DC power and the magnetic stirring apparatus. It is calculated according to the following equation [39]:

$\mathrm{W}(\mathrm{kWh} / \mathrm{g})=\frac{(\mathrm{U} * \mathrm{I}+\mathrm{P}) * \mathrm{t}}{\Delta \mathrm{X} * 1000}$

Where $U$ is the voltage (V), I is the current intensity (A), $t$ is the reaction time in $\mathrm{h}, \mathrm{P}$ is the power of magnetic stirring apparatus (15W), $\Delta \mathrm{X}$ is the recovery quality of $\mathrm{Ni}$ ions and the unit is milligramma (mg). According to Table 1, under the optimal conditions for nickel recovery and ammonia removal, the energy consumption is $0.11 \times 10^{-3} \mathrm{kWh} / \mathrm{g}$.

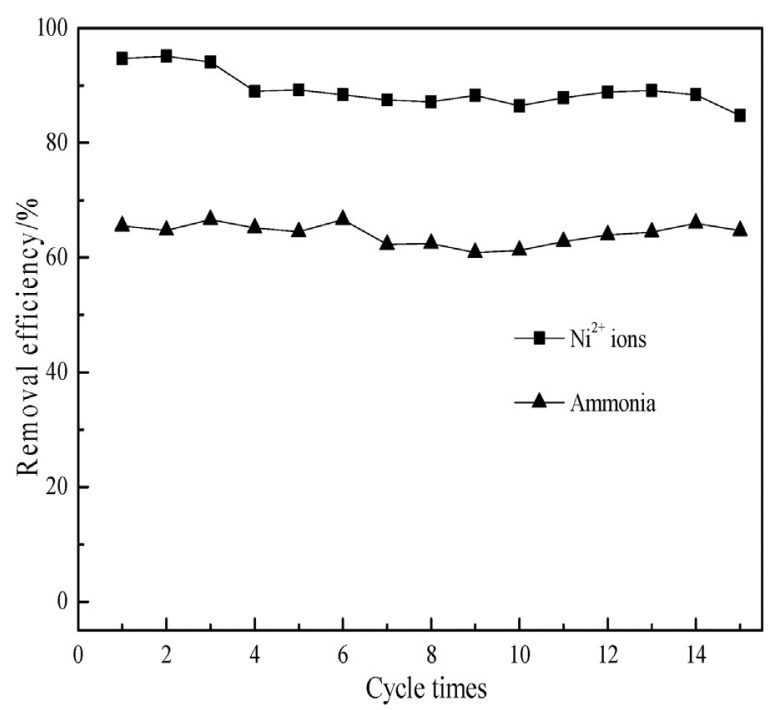

Fig. 7. Variation of nickel concentration and ammonia concentration for the repeated experiments for fifteen successive cycles (Initial concentration of $\mathrm{Ni}^{2+}$ ions, $2156 \mathrm{mg} / \mathrm{L}$; current density, $32 \mathrm{~mA} / \mathrm{cm}^{2}$; $\mathrm{pH}, 9.0$; temperature, $60^{\circ} \mathrm{C}$ ). 
Table 1

The energy consumption for recovery of $1 \mathrm{~g}$ Ni under different current densities.

\begin{tabular}{|c|c|c|c|}
\hline Current density $\left(\mathrm{mA} / \mathrm{cm}^{2}\right)$ & Voltage (V) & Current intensity (A) & Energy $(\mathrm{kWh} / \mathrm{g})$ \\
\hline 8 & 1.0, & 0.225 & $0.29 \times 10^{-3}$ \\
\hline 16 & 2.6 & 0.450 & $0.16 \times 10^{-3}$ \\
\hline 24 & 3.8 & 0.675 & $0.14 \times 10^{-3}$ \\
\hline 32 & 4.2 & 0.900 & $0.10 \times 10^{-3}$ \\
\hline 40 & 6.0 & 1.125 & $0.12 \times 10^{-3}$ \\
\hline
\end{tabular}

\section{Conclusions}

In this experiment, nickel-ammonia complexes were totally removed by a combination of electrooxidation and electrodeposition processes. Following the satisfactory results obtained from the experiment, the higher current density enhanced the oxidation ability of the anode. In addition, the $\mathrm{pH}$ and temperature influenced the existence form of ammonia in water. Therefore, when the current density was $32 \mathrm{~mA} / \mathrm{cm}^{2}, \mathrm{pH}$ was 9.0 and temperature was $60^{\circ} \mathrm{C}$, it was highly efficient for electrooxidation of nickel-ammonia complexes and electrodeposition recovery of nickel from wastewater. The mechanism of $\mathrm{Ni}$ recovery and ammonia removal was proposed. The nickel-ammonia complexes were destroyed by anode oxidation in the initial $90 \mathrm{~min}$, generating $\mathrm{Ni}^{2+}$ ions and free $\mathrm{NH}_{3}$. Then $\mathrm{Ni}^{2+}$ ions were reduced onto the cathode and the free $\mathrm{NH}_{3}$ was further oxidized by the generated $\mathrm{HOCl}$. After the repeated experiments for fifteen successive cycles, the system exhibited high stability for ammonia removal and nickel recovery.

\section{Acknowledgments}

This work was supported by National Natural Science Foundation of China (No. 51608086, 21377148); The Science and Technology Project from Chongqing (cstc2015jcyjA20027); Scientific and Technological Research Program of Chongqing Municipal Education Commission (KJ1501103).

\section{Appendix A. Supplementary data}

Supplementary data associated with this article can be found, in the online version, at http://dx.doi.org/10.1016/j. electacta.2017.06.121.

\section{References}

[1] A. Mejri, O. Fliss, K. Alouani, Bis (aminophosphine) diselenides as chemosensors for heavy metal cations: An electrochemical, spectroscopic and theoretical study, J. Electroanal. Chem. 787 (2017) 163-171.

[2] P. Liu, C. Li, X. Liang, G. Lu, J. Xu, X. Dong, W. Zhang, F. Ji, Recovery of high purity ferric phosphate from a spent electroless nickel plating bath, Green Chem. 16 (2014) 1217-1224.

[3] S. Uludag-Demirer, G.N. Demirer, S. Chen, Ammonia removal from anaerobically digested dairy manure by struvite precipitation, Process Biochem. 40 (2005) 3667-3674.

[4] Y. Huang, D. Wu, X. Wang, W. Huang, D. Lawless, X. Feng, Removal of heavy metals from water using polyvinylamine by polymer-enhanced ultrafiltration and flocculation, Sep. Purif. Technol. 158 (2016) 124-136.

[5] S. Omeiri, Y. Gabès, A. Bouguelia, M. Trari, Photoelectrochemical characterization of the delafossite $\mathrm{CuFeO}_{2}$ : Application to removal of divalent metals ions, J. Electroanal. Chem. 614 (2008) 31-40.

[6] Y. Pang, A.Z. Abdullah, S. Bhatia, Review on sonochemical methods in the presence of catalysts and chemical additives for treatment of organic pollutants in wastewater, Desalination. 277 (2011) 1-14.

[7] S. Lan, Y. Xiong, S. Tian, J. Feng, T. Xie, Enhanced self-catalytic degradation of $\mathrm{Cu}$-EDTA in the presence of $\mathrm{H}_{2} \mathrm{O}_{2} / \mathrm{UV}$ : Evidence and importance of $\mathrm{Cu}$-peroxide as a photo-active intermediate, Appl. Catal. B: Environ. 183 (2016) 371-376.

[8] C. Cheng, J. Wang, X. Yang, A. Li, C. Philippe, Adsorption of Ni(II) and Cd(II) from water by novel chelating sponge and the effect of alkali-earth metal ions on the adsorption, J. Hazard. Mater. 264 (2014) 332-341.

[9] Y.S. Dzyazko, L.N. Ponomaryova, Y.M. Volfkovich, V.V. Trachevskii, A.V. Palchik, Ion-exchange resin modified with aggregated nanoparticles of zirconium hydrophosphate. Morphology and functional properties, Micropor. Mesopor. Mat. 198 (2014) 55-62.

[10] T. Benvenuti, R.S. Krapf, M.A.S. Rodrigues, A.M. Bernardes, J. Zoppas- Ferreira, Recovery of nickel and water from nickel electroplating wastewater by electrodialysis, Sep. Purif. Technol 129 (2014) 106-112.

[11] X. Zhao, L. Guo, C. Hu, H. Liu, J. Qu, Simultaneous destruction of Nickel (II)EDTA with $\mathrm{TiO}_{2} / \mathrm{Ti}$ film anode and electrodeposition of nickel ions on the cathode, Appl. Catal. B: Environ 144 (2014) 478-485.

[12] Y. Wang, J. Wang, X. Zhao, X. Song, J. Gong, The inhibition and adaptability of four wetland plant species to high concentration of ammonia wastewater and nitrogen removal efficiency in constructed wetlands, Bioresource Technol. 202 (2016) 198-205.

[13] J. Yao, M. Zhou, D. Wen, Q. Xue, J. Wang, Electrochemical conversion of ammonia to nitrogen in non-chlorinated aqueous solution by controlling $\mathrm{pH}$ value, J. Electroanal. Chem. 776 (2016) 53-58.

[14] X. Zhang, W. Li, E.R. Blatchley, X. Wang, P. Ren, UV/chlorine process for ammonia removal and disinfection by-product reduction: Comparison with chlorination, Water Res. 68 (2015) 804-811.

[15] X. Zhao, J. Zhang, J. Qu, Photoelectrocatalytic Oxidation of Cu-cyanides and CuEDTA at $\mathrm{TiO}_{2}$ nanotube electrode, Electrochim. Acta 180 (2015) 129-137.

[16] L. Liu, R. Li, Y. Liu, J. Zhang, Simultaneous degradation of ofloxacin and recovery of $\mathrm{Cu}(\mathrm{II})$ by photoelectrocatalysis with highly ordered $\mathrm{TiO}_{2}$ nanotubes, $\mathrm{J}$. Hazard. Mater. 308 (2016) 264-275.

[17] X. Zhao, L. Guo, J. Qu, Photoelectrocatalytic oxidation of Cu-EDTA complex and electrodeposition recovery of $\mathrm{Cu}$ in a continuous tubular photoelectrochemical reactor, Chem. Eng. J. 239 (2014) 53-59.

[18] S.M. Park, S.Y. Shin, J.S. Yang, S.W. Ji, K. Baek, Selective Recovery of Dissolved Metals from Mine Drainage Using Electrochemical Reactions, Electrochim. Acta 181 (2015) 248-254.

[19] A.L. Giraldo, E.D. Erazo-Erazo, O.A. Flórez-Acosta, E.A. Serna-Galvis, R.A. Torres-Palma, Degradation of the antibiotic oxacillin in water by anodic oxidation with $\mathrm{Ti} / \mathrm{IrO}_{2}$ anodes: Evaluation of degradation routes, organic byproducts and effects of water matrix components, Chem. Eng. J. 279 (2015) 103-114.

[20] H. Lu, Y. Wang, J. Wang, Recovery of $\mathrm{Ni}^{2+}$ and pure water from electroplating rinse wastewater by an integrated two-stage electrodeionization process, J. Clean. Prod. 92 (2015) 257-266.

[21] V. Coman, B. Robotin, P. Ilea, Nickel recovery/removal from industrial wastes: A review, Resour. Conserv. Recyc. 73 (2013) 229-238.

[22] Y. Su, G. Wang, D.T.F. Kuo, M.L. Chang, Y.H. Shih, Photoelectrocatalytic degradation of the antibiotic sulfamethoxazole using $\mathrm{TiO}_{2} / \mathrm{Ti}$ photoanode, Appl. Catal. B: Environ. 186 (2016) 184-192.

[23] H. Zöllig, C. Fritzsche, E. Morgenroth, K.M. Udert, Direct electrochemical oxidation of ammonia on graphite as a treatment option for stored sourceseparated urine, Water Res. 69 (2015) 284-294.

[24] D. Reyter, D. Bélanger, L. Roué, Optimization of the cathode material for nitrate removal by a paired electrolysis process, J. Hazard. Mater. 192 (2011) 507-513.

[25] F. Fu, Q. Wang, Removal of heavy metal ions from wastewaters: a review, J. Environ. Manage. 924 (2011) 07-18.

[26] L. Li, N. Takahashi, K. Kaneko, T. Shimizu, T. Takarada, A novel method for nickel recovery and phosphorus removal from spentelectroless nickel-plating solution, Sep. Purif. Technol. 147 (2015) 237-244.

[27] H. Yue, L. Xue, F. Chen, Efficiently electrochemical removal of nitrite contamination with stable $\mathrm{RuO}_{2}-\mathrm{TiO}_{2} / \mathrm{Ti}$ electrodes, Appl. Catal. B: Environ. 206 (2017) 683-691.

[28] J. Li, J. Li, C. Wang, K. Deng, K. Sun, G. Bueln, The effect and biological mechanism of COD/TN ratio on nitrogenremoval in a novel upflowmicroaerobic sludge reactor treatingmanure-free piggery wastewater, Bioresource Technol. 209 (2016) 360-368.

[29] T.R. Jensen, A. Andreasen, T. Vegge, J.W. Andreasen, K. Ståhl, A.S. Pedersen, M. M. Nielsen, A.M. Molenbroek, F. Besenbacher, Dehydrogenation kinetics of pure and nickel-doped magnesium hydride investigated by in situ timeresolved powder X-ray diffraction, Int. J. Hydrogen Energy 31 (2006) 20522062.

[30] S. Tian, Y. Li, X. Zhao, Cyanide removal with a copper/active carbon fiber Cathode via a combined oxidation of a Fenton-like reaction and in situ generated copper oxides at anode, Electrochim. Acta 180 (2015) 746-755.

[31] C.A. Martinez-Huitle, S. Ferro, Electrochemical Oxidation of Organic Pollutants for the Wastewater Treatment: Direct and Indirect Processes, Chem. Soc. Rev. 35 (2006) 1324-1340.

[32] D. Kearney, O. Dugauguez, D. Bejan, N.J. Bunce, Electrochemical Oxidation for Denitrification of Ammonia: A Conceptual Approach for Remediation of Ammonia in Poultry Barns, ACS Sustain. Chem. Eng. 1 (2013) 190-197. 
[33] Y. Zhu, Y. Liu, Y. Gao, O. Cheng, L. Zhao, Z. Yang, Magnetic properties of aristate spherical Ni nanoparticles synthesized through ultrasound reduction method, Mater. Res. Bull 87 (2017) 135-139.

[34] I.G. Casella, M. Contursi, Pulsed electrodeposition of nickel/palladium globular particles from an alkaline gluconate bath. An electrochemical, XPS and SEM investigation, J. Electroanal. Chem. 692 (2013) 80-86.

[35] F. Contu, S.R. Taylor, Further insight into the mechanism of Re-Ni electrodeposition from concentrated aqueous citrate baths, Electrochim. Acta 70 (2012) 34-41.

[36] K. Kim, Y. Kim, I. Kim, G. Park, E. Lee, The electrolytic decomposition mechanism of ammonia to nitrogen at an $\mathrm{IrO}_{2}$ anode, Electrochim. Acta 50 (2005) 4356-4364.
[37] A. Kapałka, A. Cally, S. Neodo, C. Comninellis, M. Wächter, K.M. Udert, Electrochemical behavior of ammonia at $\mathrm{Ni} / \mathrm{Ni}(\mathrm{OH})_{2}$ electrode, Electrochem. Commun. 12 (2010) 18-21.

[38] K. Kim, Y. Kim, I. Kim, G. Park, E. Lee, Electrochemical conversion characteristics of ammonia to nitrogen, Water Res 40 (2006) 1431-1441.

[39] I.M. Sasidharan Pillai, A.K. Gupta, Performance analysis of a continuous serpentine flow reactor for electrochemical oxidation of synthetic and real textile wastewater: Energy consumption, mass transfer coefficient and economic analysis, J. Environ. Manage. 193 (2017) 524-531. 